\title{
On-farm use of legume (Phaseolus calcaratus) and Ruzi grass on rumen fermentation and milk production in lactating dairy cows
}

\author{
Metha Wanapat ${ }^{1 *}$, Narong Wongnen ${ }^{2}$, Wisith Sangkloy ${ }^{2}$, Ruangyote Pilajun ${ }^{1}$, \\ Suchittra Kanpukdee ${ }^{1}$ \\ ${ }^{1}$ Tropical Feed Resources Research and Development Center (TROFREC), Department of Animal Science, Faculty of Agriculture, \\ Khon Kaen University, Khon Kaen, Thailand; *Corresponding Author: metha@kku.ac.th \\ ${ }^{2}$ Dairy Farming Promotion Organization of Thailand, Northeast Region (DPO), Khon Kaen, Thailand
}

Received 7 January 2012; revised 12 February 2012; accepted 24 March 2012

\section{ABSTRACT}

The experiment was conducted on 10 smallholder dairy farmers under the administration of Dairy Promotion Organization of Thailand (DPO) in the Northeast region of Thailand. The aim of the research was to investigate the effect of legume (Phaseolus calcaratus, PC) as roughage mixed with Ruzi grass for dairy cows. Fours cows per farm were assigned into 2 groups including Ruzi grass (control) and PC mixed with ruzi grass (at the ratio 50:50), were given ad libitum as a roughage sources. All cows were offered a concentrate with ratio to milk yield of 1:2. The results revealed that roughage source did not affect on ruminal $\mathrm{pH}$ and temperature, ammonia nitrogen, blood urea nitrogen, and milk urea nitrogen concentrations. Total volatile fatty acid, acetic acid, propionic acid, and butyric acid proportions, and acetic acid to propionic acid ratio were not significantly different among treatments. Dry matter intake and digestibility of nutrient including dry matter, organic matter, crude protein, neutral detergent fiber and acid detergent fiber were not significantly different among treatments. Moreover, amount of digested dry mater was similar among treatments. However, cows received PC mixed with Ruzi grass tended to be higher on dry matter, organic matter, and crude protein digestibility and dry matter digestible nutrient intake than control group. Milk yield, and 3.5\% fat corrected milk were significantly higher $(P<$ 0.05) in cow fed with PC mixed Ruzi grass than those the control group. Milk compositions and feed cost were similar among treatments; in contrast, the income and profit from milk selling were greater in cows fed with PC mixed with Ruzi grass than the control. High quality roughage such as PC mixed with Ruzi grass could be advantages for dairy farming in the Northeast of Thailand.

Keywords: Phaseolus calcaratus; Ruzi Grass; Rumen Fermentation; Milk Production; Dairy Cows; Small-Holder Dairy Farmers

\section{INTRODUCTION}

Dairy farming in Thailand is rapidly increasing. However, the production of raw milk can not meet the demand of the whole country. Local milk production comprised only about $20 \%$ of the total consumption, the rest had to be imported. Practically, $95 \%$ to $99 \%$ of dairy farms in Thailand can be classified as small scale or small-holder farms under mixed crop-livestock farming systems. Feeds cost is one of the majors inputs for dairy production which are relatively abundant in Thailand, especially concentrate feeds such as fish meal, cereals, cassava chip, as well as agricultural by-products and wastes [1]. In currently, most farmers have planted only one kind of grass with much use of chemical fertilizer as soil fertility and grass improvement. The use of appropriate forage systems involving leguminous plants, dairy farming could enhance the quality of environment and ecosystem, especially improving both quality of the roughage and soil fertility especially nitrogen contain. Tau-mun (Phaseolus calcaratus) is a sprawling leguminous shrub grows well in poor soils and in dry areas. The whole crop can be sun-dried as hay and the seeds can be a nutritious protein source at three months $(17.8 \%$ to $22.1 \%$ DM) [2,3]. Wanapat et al. [3] found that Tau-mun intercrop with Ruzi grass biomass yield were 10.6 tonnes $\mathrm{DM} / \mathrm{ha}$ and $\mathrm{CP}$ was 14.1 percent of DM with NDF being 
68.9 percent and ADF 47.8 percent of DM. The data shown that Tau-mun intercrop with Ruzi grass can increase crop biomass and protein value in small-holder farmers. Moreover, condensed tannins contained in PC are able to impede the digestion of protein through a capacity to form reversible complexes with proteins [4]. Tannin-protein complexes are considered stable in the rumen ( $\mathrm{pH} 5.0$ - 7.0). However, the low $\mathrm{pH}(2.5$ - 3.5) in the abomasum as well as the high $\mathrm{pH}(8.0-9.0)$ in the small intestine can stimulate dissociation [5], contributing to "by-pass" proteins [6]. Therefore, the objective of this experiment to study effect of Phaseolus calcaratus as roughage mixed with Ruzi grass improve rumen fermentation and milk production in lactating dairy cows at small-holder dairy farms.

\section{MATERIALS AND METHODS}

The experiment was conducted on 10 small-holder dairy farmers from 4 Milk Collection Centers (Nampong, Pungtui, Kranaun in Khon Kaen province, and Srithad in Udonthani province) under the administration of Dairy Promotion Organization of Thailand (DPO) in the
Northeast region of Thailand. The experiment was done during early of winter (October to December, 2009).

\subsection{Animals and Feeds}

Randomized complete block design (RCBD) was used in this experiment. Fours early lactating Holstein Friesian crossbred dairy cows ( $\sim 82.5 \%$ Holstein Friesian $)$ per farm were assigned into 2 groups ( 2 animals/group) to received ruzi grass (control) and mixed Phaseolus calcaratus and ruzi grass (at the ratio 50:50) in ad libitum as a roughage source. Concentrate was supplemented at the same level (1:2; concentrate:milk yield) after morning (0600) and afternoon (1600) milking. Average of the ingredients and chemical compositions is shown in Table 1.

\subsection{Samples and Analysis}

Individual intakes of roughage and concentrate were recorded for 60-days period. Feeds and fecal samples were dried at $60^{\circ} \mathrm{C}$, ground $(1 \mathrm{~mm}$ screen using Cyclotech Mill, Tecator, Sweden). Samples were analysed using the

Table 1. Average of the ingredients and chemical compositions of concentrate.

\begin{tabular}{|c|c|c|c|}
\hline & $\% \mathrm{DM}$ & Ruzi grass & Phaseolus calcaratus \\
\hline \multicolumn{4}{|l|}{ Ingredients } \\
\hline Cassava chip & 60.4 & & \\
\hline Rice bran (Fined) & 13.2 & & \\
\hline Soybean meal (44\% CP) & 13.7 & & \\
\hline Brewerys' grain & 16.7 & & \\
\hline Palm kernel meal & 9.0 & & \\
\hline Coconut meal & 5.7 & & \\
\hline Urea $(46 \% \mathrm{~N})$ & 1.5 & & \\
\hline Molasses & 3.1 & & \\
\hline Sulfur & 0.2 & & \\
\hline Premix minerals (Dairy) & 1.0 & & \\
\hline \multicolumn{4}{|c|}{ Chemical composition (mean \pm SD) } \\
\hline \multirow[t]{2}{*}{ Dry matter (DM), \% } & $90.2 \pm 2.1$ & $25.1 \pm 3.3$ & $25.3 \pm 3.5$ \\
\hline & & $\% \mathrm{DM}$ & \\
\hline Organic matter & $96.7 \pm 1.7$ & $87.2 \pm 2.4$ & $88.2 \pm 3.1$ \\
\hline Crude protein & $18.5 \pm 1.3$ & $6.7 \pm 1.5$ & $17.4 \pm 2.3$ \\
\hline Neutral detergent fiber & $15.1 \pm 3.2$ & $76.6 \pm 4.6$ & $59.7 \pm 5.2$ \\
\hline Acid detergent fiber & $8.3 \pm 2.5$ & $55.1 \pm 3.7$ & $38.9 \pm 4.1$ \\
\hline Condensed tannin & - & $0.3 \pm 0.02$ & $2.2 \pm 0.09$ \\
\hline Total digestible nutrient & $73.1 \pm 3.9$ & $48.2 \pm 2.4$ & $50.3 \pm 2.8$ \\
\hline
\end{tabular}


standard methods of AOAC [7] for dry matter (DM, ID 967.03), ash (ID 942.05), and acid detergent fiber (ADF, ID 973.18). Neutral detergent fiber (NDF) in samples was estimated according to Van Soest et al. [8] with the addition of $\alpha$-amylase but without sodium sulphite and the results were calculated with residual ash. Total nitrogen $(\mathrm{N})$ in samples of feeds, feed refusals, and feces were determined according to AOAC [9] (ID 984.13). Acid insoluble ash content of feed and feces were determined for dry matter digestibility by method of Van Keulen and Young [10].

Ruminal fluids were taken from each cow via a stomach tube at $60^{\text {th }}$ day of experiment. Ruminal $\mathrm{pH}$ and temperature were determined immediately by using $\mathrm{pH}$ meter (HANNA, instruments HI 8424 microcomputer, Singapore). Ruminal fluid was analyzed for $\mathrm{NH}_{3}-\mathrm{N}$ by Kjeltec 1002 system. Volatile fatty acids (VFA) concentration in rumen fluid was analyzed by using High Pressure Liquid Chromatography (Instuments by controller water model 600E; water model 484 UV detector; column novapak C18; column size $3.9 \mathrm{~mm} \times 300 \mathrm{~mm}$; mobile phase $10 \mathrm{mM} \mathrm{H} 2 \mathrm{PO} 4$ [pH 2.5]) according to Samuel et al. [11]. Blood samples were analyzed for blood-urea nitrogen [12].

Daily milk yield of each cow was recorded and milk was sampled twice a month. Samples from the evening and the morning milking of each cow were pooled (70:30) and stored in a refrigerator at $4^{\circ} \mathrm{C}$ until they were analysed for fat, crude protein, lactose, solid-not-fat and total solids by an infra-red analyzer (MILKOSCAN). Milk production costs and income were calculated.

\subsection{Statistical Analysis}

All data were statistical analyzed using the general linear procedure in PROC GLM of SAS [13]. Data were analyzed using the model Yijk $=\mu+\mathrm{Bi}+\mathrm{Tj}+$ cijk where; Yijk = observation from block $\mathrm{i}$ and treatment $\mathrm{j}, \mu=$ the overall mean, $\mathrm{Bi}=$ the mean of block (small-holder farm), $\mathrm{Tj}=$ the mean of treatment (roughage source), and cijk = the residual effect. Differences between treatment means were determined by Duncan's New Multiple Range Test [14]. Differences among means with $\mathrm{P}<0.05$ were accepted as representing statistically significant differences.

\section{RESULTS AND DISCUSSION}

Average protein content in Ruzi grass and PC were $6.7 \%$ and $17.4 \%$ of DM while condensed tannin content were $0.3 \%$ and $2.2 \%$ of DM, respectively (Table 1). However, Chanthakhoune and Wanapat [15] reported that crude protein and condensed tannin contents in PC hay were higher than $18.3 \%$ and $2.8 \%$, respectively. Fluctuate of chemical compositions of PC may be due to the differences of the season, soil quality, cultivation concentration, etc.

It was found that total feed intake, roughages intake and concentrate intake tended to be lower in control group were not significantly different among treatments $(\mathrm{P}>0.05)$ although it was (Table 2$)$. This may cause by in the beginning we designed to give concentrate to animal at $1 \mathrm{~kg}$ of concentrate per $2 \mathrm{~kg}$ of milk yield. However, Wanapat et al. [2] suggested that high quality of roughages can reduce concentrate feed for the animals. High quality of roughage means high content of available crude protein and easily degradable carbohydrate fractions particularly starch and sugar. These properties will lead rumen microbes to more digest of roughage, proving more nutrients to host animal, and then decreased of need of concentrate supplementation [16]. Digestibility of dry matter, organic matter, crude protein, and fiber

Table 2. Effect of Phaseolus calcaratus mixed with Ruzi grass as roughage on voluntary feed intake and nutrient digestibility.

\begin{tabular}{lcccc}
\hline & Control & PC + Ruzi & SEM & P-value \\
\hline Total feed intake, $\mathrm{kg} / \mathrm{hd} / \mathrm{d}$ & 15.0 & 14.5 & 0.47 & 0.54 \\
Roughages intake, $\mathrm{kg} / \mathrm{hd} / \mathrm{d}$ & 7.8 & 7.5 & 0.55 & 0.22 \\
Concentrate intake, $\mathrm{kg} / \mathrm{hd} / \mathrm{d}$ & 7.2 & 7.0 & 0.23 & 0.75 \\
Digestion coefficients, \% & & & 0.46 \\
Dry matter & 57.0 & 58.8 & 0.52 & 0.56 \\
Organic mater & 59.3 & 59.9 & 0.26 & 0.66 \\
Crude protein & 58.2 & 58.7 & 0.36 & 0.19 \\
Neutral detergent fiber & 47.3 & 45.3 & 0.39 & 0.23 \\
Acid detergent fiber & 36.5 & 35.1 & 8.9 & 0.43 \\
DM digestible nutrient intake, $\mathrm{kg} / \mathrm{hd} / \mathrm{d}$ & 8.5 & & 0.37 \\
\hline
\end{tabular}

$\mathrm{PC}+\mathrm{Ruzi}=$ Phaseolus calcaratus mixed with Ruzi grass at $1: 1 ; \mathrm{SEM}=$ standard error of the means 
fractions (neutral detergent fiber and acid detergent fiber) were similar among treatments $(\mathrm{P}>0.05)$. However, cows received Ruzi grass mixed with $\mathrm{PC}$ tended to be higher in DM, OM and CP digestibility and DM digestible nutrient intake than control group. Our hypothesis was increasing of roughage quality especially enhancing of protein content could improve digestibility of dairy cow; however, it was not presented. Groff and Wu [17] found that apparent digestibility of dry matter increased linearly as the protein content of the diet was increased. However, changes in dry matter digestibility with dietary protein level were inconsistent, as it has been in the literature. Cunningham et al. [18] reported similar organic matter digestibility when diets contained $14.5 \%$ to $18.5 \%$ $\mathrm{CP}$, and in agreed with Wattiaux and Karg [19] who showed no changes in dry matter digestibility when dietary protein was changed from $16.5 \%$ to $17.7 \%$. On the other hand, decreasing dietary protein has been reported to result in decreases [20,21] or no changes [22] in protein apparent digestibility. In addition, tannins are generally regarded as inhibitory to the growth of rumen microorganisms. It could be advantageous to specifically inhibit protein degrading bacteria in the rumen. Condensed tannin in L. corniculatus inhibited the growth of Clostridium proteoclasticum, B. fibrisolvens, Eubacterium spp. R. albus, F. succinogenes and $S$. bovis, and the rate of proteolysis in vitro [23]. Diaz et al. [24] shown supplementation with plant containing saponins and/or tannins resulted in decreased apparent digestibility of ruminant. Moreover, inclusion of 30\% Calliandra leaves containing tannins in the diet significantly reduced total cellulolytic bacteria [25]. The present study indicated that animal received condensed tannin from PC at low level which it not impact on digestion of feed by rumen microbes.

The ruminal $\mathrm{pH}$ and temperature were similar among treatments $(\mathrm{P}>0.05)$ and were in normal ranges (Table 3 ), which have been reported as optimal for microbial digestion of fiber $\left(39^{\circ} \mathrm{C}\right.$ to $41^{\circ} \mathrm{C}$ and 6.5 to 7.0 , respecttively) as mentioned by Wanapat [16]. Moreover, it may confirm that cow obtained an appropriate level of roughage to concentrate ratio for optimum of rumen fermentation. Results from many studies have shown that rumen fermentation is generally change when animal fed with difference of forage to concentrate ratio [26,27]. Furthermore, diets higher in non-structural carbohydrate such as starch normally cause of a decrease in microbial growth efficiency due to a decrease in ruminal $\mathrm{pH}$ and a slower ruminal passage rate [28]. Concentrations of ammonia nitrogen $\left(\mathrm{NH}_{3}-\mathrm{N}\right)$, blood urea nitrogen, milk urea nitrogen, and total volatile fatty acid were not significantly different among treatments $(\mathrm{P}>0.05)$. Moreover, proportion of individual volatile fatty acids including acetic acid, propionic acid and butyric acid were not affected by roughage type $(\mathrm{P}>0.05)$. The results were agreed with effects on feed intake and nutrient digestibility which were not affected by roughage type. In contrast, Hungate [29] stated that enhancing of protein digestion in the rumen will result in increasing of branch-chain fatty acid (such as iso-butyric acid) proportion.

Milk yield, and 3.5\% fat corrected milk yield were significantly higher $(\mathrm{P}<0.05)$ in cows fed with Ruzi grass mixed with $\mathrm{PC}$ than control group $(\mathrm{P}<0.05)$. Although milk fat tended to be higher in cows received grass mixed, other milk compositions were similar among treatments $(\mathrm{P}>0.05)$. Income and profit from milk selling was higher in cows fed with mixed grass when compared with the control group $(\mathrm{P}<0.05)$; whereas, feed cost for milk production was similar among treatments (P > 0.05; Table 4). These results can implied that mixed of Ruzi grass with PC could enhance whole body nutriaent utilization of dairy cows particularly protein utilizetion. Condensed tannins contained in PC are able to delay the digestion of protein through a capacity to form reversible complexes with proteins (Tannin-protein complex) [4]. Tannin-protein complexes are considered stable in the rumen $(\mathrm{pH} 5.0$ - 7.0). However, the low $\mathrm{pH}$ $(2.5$ - 3.5) in the abomasum as well as the high $\mathrm{pH}(8.0-$ 9.0) in the small intestine can stimulate dissociation [5], contributing to "by-pass" or rumen-undegradable proteins $[4,6]$. Efficiency of nitrogen utilization could be improved by increasing post-ruminal digestibility and/or providing a pattern of absorbed amino acid that more closely matches the amino acid requirements for milk synthesis. The NRC [30] recognize this distinction by describing dietary crude protein as being either ruminally degraded to support microbial growth or ruminally undegraded to supplement rumen microbial protein to meet metabolizable protein requirements. However, Ipharraguerre and Clark [31] reviewed that because of the large variation and small magnitude of response when rumenundegradable proteins are supplemented, efficiency of nitrogen utilization and the cost-to-benefit ratio for these crude protein supplements may determine the source and amount of crude protein to feed to dairy cows in the future.

\section{CONCLUSION}

Roughage source did not affect on feed intake, nutrient digestibility, and rumen fermentation although it tended to by higher in cow fed with PC mixed with Ruzi grass than control group. Although milk composition was not affect by treatments, milk yield, milk income and profit were enhanced by high quality roughage (PC mixed with Ruzi grass). Condensed tannin contained in PC may play action in providing to by-pass protein to dairy cow and enhanced their performance. Thus, high quality roughage 
Table 3. Effect of Phaseolus calcaratus mixed with Ruzi grass as roughage on ruminal fermentation.

\begin{tabular}{lcccc}
\hline & Control & PC + Ruzi & SEM & P-value \\
\hline Ruminal pH & 6.4 & 6.6 & 0.26 & 0.51 \\
Rumen temperature, ${ }^{\circ} \mathrm{C}$ & 38.7 & 38.4 & 0.14 & 0.76 \\
$\mathrm{NH}_{3}-\mathrm{N}, \mathrm{mg} \%$ & 14.5 & 16.5 & 1.97 & 0.07 \\
Blood urea nitrogen, $\mathrm{mg} \%$ & 15.0 & 16.9 & 1.65 & 0.09 \\
Milk urea nitrogen, mg\% & 15.4 & 16.0 & 1.83 & 0.29 \\
Total volatile fatty acid (TVFA), mmol/L & 105.9 & 106.9 & 1.97 & 0.29 \\
$\quad$ Acetic acid (C2), \%TVFA & 65.9 & 65.7 & 1.55 & 0.44 \\
$\quad$ Propionic acid (C3), \%TVFA & 27.4 & 26.5 & 1.39 & 0.25 \\
Butyric acid (C4), \%TVFA & 7.8 & 6.6 & 0.69 & 0.10 \\
C2/C3 ratio & 2.4 & 2.5 & 0.07 & 0.32 \\
\hline
\end{tabular}

PC + Ruzi = Phaseolus calcaratus mixed with Ruzi grass at 1:1; SEM = standard error of the means.

Table 4. Effect of Phaseolus calcaratus mixed with Ruzi grass as roughage on milk production and economic return.

\begin{tabular}{lcccc}
\hline & Control & PC + Ruzi & SEM & P-value \\
\hline Milk production, kg/hd/d & 16.8 & 18.3 & 0.41 & 0.04 \\
$3.5 \%$ FCM, kg/hd/d & 17.3 & 20.9 & 0.37 & 0.04 \\
Milk compositions, \% & & & \\
Fat & 3.6 & 3.8 & 0.16 & 0.28 \\
Protein & 3.2 & 3.3 & 0.43 & 0.69 \\
Lactose & 4.6 & 4.6 & 0.71 & 0.87 \\
Total Solid & 11.2 & 11.1 & 0.75 & 0.52 \\
Solid not fat & 8.2 & 8.1 & 0.68 & 0.76 \\
Economic return, US/hd/d & & & & \\
Feed cost & 2.03 & 2.07 & 0.83 & 0.73 \\
Milk income & 8.62 & 9.71 & 0.26 & 0.04 \\
Profit & 6.59 & 7.64 & 0.13 & 0.03 \\
\hline
\end{tabular}

$\mathrm{PC}+\mathrm{Ruzi}=$ Phaseolus calcaratus mixed with Ruzi grass at $1: 1 ; \mathrm{SEM}=$ standard error of the means.

such as PC mixed with Ruzi grass could be advantages for dairy farming in the Northeast of Thailand.

\section{ACKNOWLEDGEMENTS}

The authors are grateful for Tropical Feed Resources Research and Development Center (TROFREC), Dairy Farming Promotion Organization of Thailand (DPO) - North East and small-holder dairy farmers for providing the research financial and facilities support of the research.

\section{REFERENCES}

[1] Chantalakana, C. and Skunmun, P. (2002) Sustainable smallholder animal systems in the tropics. Kasetsart University Press, Bankkok.

[2] Wanapat, M., Poungchompu, O., Joomjunta, S., Lunsin, R., Heebkaew, R. and Petlum, A. (2006) Study on growth and nutritive values of Phaseolus calcaratus. Annual report of the Tropical Feed Resources Research and Development Center, Khon Kaen University, Khon Kaen.

[3] Wananpat, M., Wongnen, N., Sangkloy, W., Tamkornburi, P., Kingkratoke, S., Sukarin, A., Yotikoun, S., Narksuwan, M., Sirinawakoun, W. and Kanpukdee, S. (2010) Approaches in producing Phaseolus calcaratus as a roughage intercrop with ruzi grass for dairy cows on smallholder dairy farms. Proceedings of the 11th Agricultural Conference, Khon Kaen, 25-26 January 2010, 330-333.

[4] McNeill, D.M., Osborne, N., Komolong, M.K. and Nan- 
kervis, D. (1998) Condensed tannins in the genus Leucaena and their nutritional significance for ruminants. Proceedings of ACIAR in Leucaena-Adaptation, Quality and Farming Systems, Hanoi, 9-14 February 1998, 86.

[5] Perez-Maldonado, R.A., Norton, B.W. and Kerven, G.L. (1995) Factors affecting in vitro formation of tanninprotein complexes. Journal of the Science of Food and Agriculture, 69, 291-298. doi:10.1002/jsfa.2740690305

[6] Perez-Maldonado, R.A. and Norton, B.W. (1996) The effects of condensed tannins from Desmodium intortum and Calliandra calothyrsus on protein and carbohydrate digestion in sheep and goats. British Journal of Nutrition, 76, 515-533. doi:10.1079/BJN19960060

[7] AOAC (1995) Official method of analysis. 16th Edition, Animal Feeds: Association of Official Analytical Chemists, Virginia.

[8] Van Soest, P.J., Robertson, J.B. and Lewis, B.A. (1991) Methods for dietary fiber neutral detergent fiber, and nonstarch polysaccharides in relation to animal nutrition. Journal of Dairy Science, 74, 3583-3597. doi:10.3168/jds.S0022-0302(91)78551-2

[9] AOAC (1991) Official methods of analysis. 15th Edition, Association of Official Analytical Chemists, Washington DC.

[10] Van Keulen, J. and Young, B.A. (1977) Evaluation of acid insoluble ash as a neutral marker in ruminant digestibility studies. Journal of Animal Science, 44, 282-287.

[11] Samuel, M., Sagathewan, S., Thomas, J. and Mathen, G. (1997) An HPLC method for estimation of volatile fatty acids of ruminal fluid. Indian Journal of Animal Science, 67, 805-807.

[12] Bremmer, J.M. and Keeney, D.R. (1965) Steam distillation methods to determination of ammonium, nitrate and nitrite. Analytica Chimica Acta, 32, 485-495. doi:10.1016/S0003-2670(00)88973-4

[13] SAS (1996) SAS user's guide: Statistic. 5th Edition, SAS Institute, Cary.

[14] Steel, R.G.D. and Torrie, J.H. (1980) Principles and procedures of statistics: A biometrical approach. 2nd Edition, McGraw-Hill Inc., New York.

[15] Chanthakhoune, V. and Wanapat, M. (2010) Effect of legume (Phaseolus calcaratus) hay supplementation on rumen cellulolytic bacterial populations in swamp Bbuffaloes investigated by the real-time PCR technique. Journal of Animal and Veterinary Advances, 9, 1654-1659. doi:10.3923/javaa.2010.1654.1659

[16] Wanapat, M. (1999) Feeding of ruminants in the tropics based on local fed resources. Khon Kaen Publishing Co. Ltd., Khon Kaen.

[17] Groff, E.B. and Wu, Z. (2005) Milk production and nitrogen excretion of dairy cows fed different amounts of protein and varying proportions of alfalfa and corn silage. Journal of Dairy Science, 88, 3619-3632. doi:10.3168/jds.S0022-0302(05)73047-2

[18] Cunningham, K.D., Cecava, M.J., Johnson, T.R. and Ludden, P.A. (1996) Influence of source and amount of dietary protein on milk yield by cows in early lactation.
Journal of Dairy Science, 79, 620-630. doi:10.3168/jds.S0022-0302(96)76407-X

[19] Wattiaux, M.A. and Karg, K.L. (2004) Protein level for alfalfa and corn-silage based diets: I. Lactational response and milk urea nitrogen. Journal of Dairy Science, 87, 3480-3491. doi:10.3168/jds.S0022-0302(04)73483-9

[20] Kauffman, A.J. and St-Pierre, N.R. (2001) The relationship of milk urea nitrogen to urine nitrogen excretion in Holstein and Jersey cows. Journal of Dairy Science, 84, 2284-2294. doi:10.3168/jds.S0022-0302(01)74675-9

[21] Broderick, G.A. (2003) Effects of varying dietary protein and energy levels on the production of lactating dairy cows. Journal of Dairy Science, 86, 1370-1381. doi:10.3168/jds.S0022-0302(03)73721-7

[22] Noftsger, S. and St-Pierre, N.R. (2003) Supplementation of methionine and selection of highly digestible rumen undegradable protein to improve nitrogen efficiency for milk production. Journal of Dairy Science, 86, 958-969. doi:10.3168/jds.S0022-0302(03)73679-0

[23] Min, B.R., Attwood, G.T., McNabb, W.C., Molan, A.L. and Barry, T.N. (2005) The effect of condensed tannins from Lotus corniculatus on the proteolytic activities and growth of rumen bacteria. Animal Feed Science and Technology, 121, 45-58. doi:10.1016/j.anifeedsci.2005.02.007

[24] Diaz, A., Avendano, M. and Escobar, A. (1993) Evaluatation of Sapindus saponaria as a defaunating agent and its effects on different ruminal digestion parameters. Livestock Research for Rural Development, 2, 1-6. http://www.lrrd.org/lrrd5/2/cefe.htm

[25] McSweeney, C.S., Palmer, B., McNeill, D.M. and Krause, D.O. (2001) Microbial interactions with tannins: Nutritional consequences for ruminants. Animal Feed Science and Technology, 91, 83-93. doi:10.1016/S0377-8401(01)00232-2

[26] Ørskov, E.R. (1992) Protein nutrition in ruminants. 2nd Edition, Academic Press, London, 41-93.

[27] Vanzant, E.S., Cochran, R.C. and Titgemeyer, E.C. (1998) Standardization of in situ techniques for ruminant feedstuff evaluation. Journal of Animal Science, 76, 2717 2729.

[28] Mabjeesh, S.J., Arieli, A., Brucental, I., Zamwell, S. and Tagari, H. (1997) Effect of ruminal degradability of crude protein and nonstructural carbohydrates on the efficiency of bacterial crude protein synthesis and amino acid flow to the abomasums of dairy cows. Journal of Dairy Science, 80, 2939-2949. doi:10.3168/jds.S0022-0302(97)76260-X

[29] Hungate, R.E. (1966) The rumen and its microbes. Academic Press, New York and London.

[30] National Research Council (2001) Nutrient requirements of dairy cattle. 7th Revised Edition, National Academy of Sciences, Washington DC.

[31] Ipharraguerre, I.R. and Clark, J.H. (2005) Varying protein and starch in the diet of dairy cows. II. Effects on performance and nitrogen utilization for milk production. Journal of Dairy Science, 88, 2556-2570. doi:10.3168/jds.S0022-0302(05)72932-5 